Journal of Social Sciences (COES\&RJ-JSS)

ISSN (E): 2305-9249 ISSN (P): 2305-9494

Publisher: Centre of Excellence for Scientific \& Research Journalism, COES\&RJ LLC

Online Publication Date: $1^{\text {st }}$ October 2019

Online Issue: Volume 8, Number 4, October 2019

https://doi.org/10.25255/jss.2019.8.4.594.610

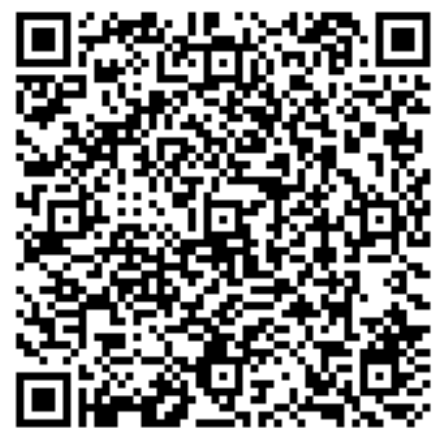

\title{
Jordanians' youth fears and their relationship to some variables
}

Dr. Salem A .S. Al-Harhasha - Assistant Professor,

Faculty of Arts, Irbid National University, Jordan

Email: salemhmood58@yahoo.com

Abstract:

The present study aims at identifying the fears of Jordanian youth. The sample included (255) young male and female. The study tool validity was confirmed by using the coefficient of internal consistency of(0.94). The results indicated that the total average mean of the degree of fear among Jordanian youth reached (3.15) and by percentage of (63\%). In addition, there were statistically significant differences in the level of fearamong the youth related to the gender variable (males and females) at the level of alpha $(\alpha=0.05)$, in favor forfemales. There were statistically significant differences at the level of $(\alpha=0.05)$ between selffears and social fears, and favor of the social fears, while there were no statistically significant differences attributed to the variable of age and the institution of education. Further, the researcher recommends conducting further studies that addressing the youth needs and psychological pressures, and building a training programs and guidance; in order to face those fears.

Keywords:

Fears, young people, self-fears, social fears

Citation:

Al-Harhasha, Salem A. S. (2019); Jordanians' youth fears and their relationship to some variables; Journal of Social Sciences (COES\&RJ-JSS), Vol.8, No.4, pp:594610; https://doi.org/10.25255/jss.2019.8.4.594.610.

This work is licensed under a Creative Commons Attribution 4.0 International License. 


\section{Introduction:}

Youth is an important level in the human's life, which largely determines most of the youth's behaviours, while this period is characterized by achievements and seeking towards achieving goals (Baha al-Din, 1998: 1). In fact, Youth is a vital levelin The Arab World; 34.5\% of the people are under the age of 15, and19.5\% from the age of 15-24 years (Sheikli, 1995: 8). In Jordan, the percentage of youth of both genders in the age group of $15-24$ are $(20.2 \%)$ for males and (19.5\%) for females, and for the age group $<19$ years (54\%), while the age group of $0-30$ years are $(74 \%)$ of the Kingdom's population. In addition, more than $38 \%$ of the Jordanian people had finished secondary schools and above, while $96 \%$ of the present enrolled students are from theYouth (Department of Statistics, 2018: 7). However, the level of Youth is considered to be one of the most challenging stagesthat families face; because of the changes that occur for the youth in the different aspects; family, social, and cultural aspects. Whereby, from the emotional aspect, this stage is characterizes by the discrepancy between admiration, self-loving and showing off, and between hate andlnsurgency on the school and the family; resultinga state of instability (Pryanka, 2013).

In addition, young people also suffer from loss of hope, which leads for mental disorders in the future (Badr, 2003: 52). In this era, the societies, official and civil bodies, in addition to education, psychology, and sociology scholars, paid a dramatic shift of attention to investigate youth problems, care and education (Abu Alnasr, 2015: 5), besides conducting researches which were directed to reach and create the appropriate environment for youth; in order to pass this level safely (Bahi, 2009: 3).

\section{The Importance of study:}

Youth serviceis an urgent necessity for this age level, as this level is characterized by growth andchange. A level that includes many problems and difficulties, which resulted from changes in all aspects of personality (Al-Majdoub, 2001: 5). As youth constitute a large proportion of the society, it makes it important to study the problems that they face; because this level bears the characteristics of both previous and subsequent age levels (Mansouri, 1429 HA: 15).

As well as, the importance of this study lies in underlying the significant Jordanian youth fears, and directing the officials to prepare training and guiding programs; in order to meet the fears that youth might encounter, and increasing their psychological security.

In addition, conducting such a study may fill the lack of researches relatedto the fears of the Jordanian youth.As well as, this study give a perception tothe academic membersand the management of the university, teachers in schools, 


\section{Jordanians' youth fears and their relationship to some variables}

and youth centers and supervisors about the problems that might encounter young people; in order to reach some recommendations that would mitigate the effects of this phenomenon.

\section{Objectives of the study:}

The present study aims to identify the fears of the Jordanian youth from their point of view. To achieve this goal, the following questions should be answered:

- What are the main fears of the Jordanian youth?

- Are there any statistically significant differences in the degree of Jordanian youth fear attributed to the gender variable (males, females)?

- Are there any statistically significant differences in the degree of Jordanian youth fears attributedto the age group (15-18, 19-25)?

- Are there any statistically significant differences in the degree of fears attributed to the type of institution to which the youth belong (school, youth center, and university)?

- Are there any statistically significant differences in the degree of youth fearsattributedto the fields of study (self, social)?

\section{Limitations of the study:}

The present study is limited to the students of Irbid National University within the age group (19-25), students of the first grade secondary class, and members of youth centers (males and females) within the age group (15-18) from JarashQasabah during the second semester of the academic year 2018/2019.

\section{Procedural terminologies:}

\subsection{Fear: Fear has many definitions, including:}

A. Fear is "a natural reaction to a real or imaginary illusion that is integrated and compatible with the reality of the child and his primary developmental functions" (Abu Zaid, 2009: 19).

B. Fear is an "unpleasant strong emotion that is resulted from the sense and expectation of a certain danger" (Al-Fawwal, 2006: 4).

C. Fear is an "acute emotional distress or anxiety motivated by withdrawal or escape from a situation caused by fear" (Good, 1973: 79).

D. Fear is an "emotion aroused by dangerous situations or knowledge of the danger that one finds difficult to confront" (William, 1976: 198).

Reviewing the previous definitions, we find three elements that consist the sense of fear; trying to escape or avoiding fearstimulates, self-fearing experience, and physical-Psychological changes. The researcher defines the sense of fear as "Interior feeling thatyouth experience and lead him to the negativity, 
resentment, and the sense of insecurity, while fear is determined through thetotal degree of sensation which specified in the study tool".

4.2. Youth: It was noted that there are three trends to define the concept of youth, and represented in the following:

A. The Biological Trend:it is basicallybased on the criterion of age; where it was agreed globally, Arab world and in Jordan to determine the range of youth level as between the age of 15-25 years, and in some developed countries, they add the ages (12, 13 and 14 years) to the youth level (Bahaa El-Din, 1998: 7).

B. The Psychological Trend: The owners of this trend do not recognize the limits of age for youth level; they believe that youth is linked to the individual psychological state, which is characterized by the vitality, ability to learn, the flexibility of human relations, and the ability to take responsibility (Sarhan, 2000: 17).

C. The Social Cultural Trend: The owners of this trend tried to connect between the aforementioned two trends; because age is important to the human, but age alone is not enough, and the importance of the psychological status, but it is not enough alone. Therefore, connection between the two trends leads to build the social cultural trend (Sarhan, 2000: 17).

However, both concepts hold a great deal of conformity to reality; many people in the youth level seem to be very old, full of despair, laziness and escape from life. While, many men, who are over the age of youth, arefull of youth vitality, energy, and hold the youth spirit and features;courageous and optimistic. The researcher defines Youth as "the age level that fall under the age period of (1525) years old".As well as, this definition is approved in the study tool.

\section{Nature and Importance of Fear:}

Fear is a congenital readiness for every human being, and a fundamental aspect of self-preservation requirements (Harhasha, 2014: 193).Fear is a natural feeling, since there are reasonable stimulates forthe person's fears. As well as, it isnot a bad feelingthat require to be eliminated; because it is one of the most important motives for the individual in order to act in response against the disorder andreach the security and stability (Girgis, 1993: 8). While the degree of fear varies from one person to another; depending on many variables related to age, source of fear, intensity of fear, and the environmental circumstancesthat the individual experience (Theo Tsaousidis, 2018).

Therefore, It is possible to distinguish between the normal from the up normal fear; through measuring the continuity and intensity of the fear, and the harmful consequences of feeling afraid for the individual in an attempt to avoid the stimulating situations (Goodwin \&Guze, 1979). 


\section{Jordanians' youth fears and their relationship to some variables}

A wide variety of interpretations were paid to discuss the sense of fear; some of which consider the sense of fear as patterns of wrong responses and their relationship to unpleasant stimuli (Sha'rawi, 1988: 30).However, the school of psychoanalysis believes that childhood is one of the most important levels in the formation of a child's personality, and fear develops due to the absence of a source of satisfying the needs of the child and the loss of love (Rabee, 1991: 18).

In addition, fear and anxiety are the most common and interrelated emotions affecting the individual (Basher, 2009: 135).Therefore, many researchers consider that what distinguishes fear from anxiety is that the fear is known and understood by the person, and that the feeling of fear is parallel to the intensity of the subject. However, anxiety is more acute and long stay, while fear is a temporary feeling. Fear may be self-oriented or subjectedto social circumstances; where self-oriented fears confuse the individual and deprive him/ her to feel happy aloneor with others, while social fears are unacceptable; leading to shape constraints among the individual's interactions, and enhance the sense of fear from talking and interacting or the fear of others critique (Gavri, 3: 2013).

In addition, psychological studies indicate that fulfilling the individual's demands and psychological needs have a key role in achieving psychological stability and a sense of security and reassurance (Zahran, 2003: 86; Wail 2004: 310). As well as, the results of the study which conducted by the Center of Youth Studies and Researches (2006) showed that $12.6 \%$ suffer from psychological problems, $44 \%$ are suffering from anxiety, $36.1 \%$ have difficulty in making decisions, $36.7 \%$ feel afraid of failure in their study. As well as, Goodwin \&Guze (1979) states that the results of studies have shown that the prevalence of up normal fears among youth is estimated at (77) per thousand (Goodwin\&Guze, 1979: 108).

\section{Study procedures:}

\subsection{Sample of the study}

Consisted of (255) youth; males and females, of Irbid National University students, schools students and members of youth centers in JarashQasabah. The total number of males was 102 with percentage (40\%), while the total number of females reached (153) with percentage (60\%).

\subsection{Study Tool:}

\subsubsection{Validity and stability of the tool:}

To verify the validity of the tool, it was presented to a committee of arbitration and specialists. After the revision, some important amendments were conducted, and the total paragraphs became (38) paragraph, as shown in Annex (1). To verify the stability of the tool, it was distributed for two areas: 
1. Self-oriented fears identified in paragraph (1-20)

2. Social Fearsidentified in paragraph (21-38).

Several methods were used to ensure that the tool was stable as shown in Table (1).

(Table 1) Cochran Bach alpha consistency coefficient, relational stability and relative decomposition of fields and total grade.

\begin{tabular}{|l|r|l|l|}
\hline & Repetition stability & $\begin{array}{l}\text { Guttmann Midterm } \\
\text { Retail }\end{array}$ & $\begin{array}{l}\text { Internal } \\
\text { consistency }\end{array}$ \\
\hline $\begin{array}{l}\text { Self-Oriented } \\
\text { fears }\end{array}$ & 0.91 & 0.83 & 0.92 \\
\hline Social fears & 0.88 & 0.84 & 0.91 \\
\hline Total score & 0.921 & 0.85 & 0.94 \\
\hline
\end{tabular}

7. Results Analysis and Discussion:

In order to answer the first question; related to the most important fears of Jordanian youth from their point of view, the mathematical averages and standard deviations were extracted to the degree of feeling for each of the paragraphs of the study (38), which were discussed as follows:

- First: the presentation of the paragraphs in general regardless of their scope.

- Second: the presentation of the paragraphs according to the fields arranged descending.

In the light of the gradual measure of the study tool of the fear questionnaire, and based on the previous studies (Alnaji, 1995:79), the consultation of many specialists in measurement and evaluation, and to reveal the degree of feelings of fear among Jordanian youth, the researcher adopted three levels of analysis of the paragraphs of the study, (3.5) or more per paragraph represents a high and true degree of feeling (70\%) or more. The paragraph that obtained an average of (3) to less than (3.49) represents the average degree of feeling which is equivalent to $60 \%$ To less than (70\%) and Anbar paragraph, which obtains an average of less than (3) meanAakech paragraphs that get Drahh great feeling because they represent the most important fears that the Jordanian youth (Shakil, 1995: 106).

7.1. First: Fears of Jordanian youth regardless of their areas:

The results presented in Appendix (1) indicate that the degrees that express the youth responses about their fear degree assessment, which included in the study instrument (38 paragraphs), ranged between (4.20) asthe max degree with percentageof $(84.2 \%),(2.42)$ with percentage $(48 \%)$ as lowest, and the mean of 
the instrument as a whole (3.15) with percentage (63\%) as shown in Table (2). According to the standard adopted by the researcher, it was found that there were (6) paragraphs of high fear levels, fear of punishment from God, fear of the spread of drugs, fear of road accidents, fear of low level of education, fear of meditation. The fear of malignant diseases and the fear of the unknown future, where the mean of the paragraph "I fear punishment of God" was 4.20 and with percentage 84.2\%; which have a high degree of fear among Jordanian youth, which related to the field of self- oriented fears. The study of Hekmat (1988) shows that the reason for fear of punishment is due to the lack of religious worships.

In this regard, (Abdel-Moneim El-Meligy and Mohamed Helmy, 1973) found that about (50\%) of youth have faith as a tradition, $(25 \%)$ are enthusiastic and $(24 \%)$ are doubtful, and (1\%) are atheists. As well as, they found that (61\%) of females faith is based on thoughts, (26\%) were enthusiastic and (13\%) were doubtful (Zahran, 1994: 3).

The youth also expressed their fear of the spread of drugs, and this is believed to be a fear of the spread of the phenomenon of drugs among Jordanian youth again for the spread of poverty, and what Jordan faces crises of asylum and wars in neighboring countries. The youth also expressed fear about the increase of road accidents. The researcher believes that this is due to the low level of the infrastructure of road rehabilitation, and therefore the increase in accidents, low level of education, fear of moderation and favoritism, and this may be due to the spread of poverty and unemployment and the suffering of the state from high indebtedness.

\subsection{Second: Presentation of the paragraphs according to the fields of study:}

Table (2) shows that the social field obtained an average of (3.26) and (65\%), which was higher than the self-fears among Jordanian youth, which obtained an average of (3.05) and (61\%).

(Table 2) Mean and standard deviations of the fields of study are ranked descending by averages

\begin{tabular}{|l|l|l|l|l|}
\hline Rank & No. & Item & Average & deviation \\
\hline 1 & 2 & Social fears & 3.26 & .905 \\
\hline 2 & 1 & Fading fears & 3.05 & .889 \\
\hline & & & & .836 \\
\hline
\end{tabular}




\section{A: The first area: Self- Oriented Fears:}

The first category of self-fears ranged from (4.20) percentage $(84.2 \%)$ to higher (2.42) and lower (48.4\%) related to the fear of speaking out loud. It is noticed from Annex (2) that there are two paragraphs expressing feeling (18) fear of God's punishment. The reason may be due to the Jordanian youth's awareness of their faith and their education on the fear of God. This result is consistent with the Hikmat study (1988) fearing the fears of university students, which was primarily fear of punishment of God.

Paragraph (20), which indicates the feeling of Jordanian youth to a high degree of fear of malignant diseases, This may be due to the fact that Jordanian youth are aware of the increase in the spread of malignant diseases (such as cancer and AIDS), which requires official bodies and non-governmental sectors to take all necessary measures to alleviate these diseases, whether preventive or therapeutic.

This result is a study (and Bahauddin (1998) T showed the spread of fears related to the aspirations of young people and their future and the lack of access to work guaranteed, and the spread of modesty and favoritism.

\section{B: The second area: Social fears:}

It is noted in Appendix 3 that there are four paragraphs indicating the degree to which social fears are high. (37), which refers to "fear of the spread of drugs" with an average of (3.81), a rate of (76\%) and a paragraph (38), "fear of increasing road accidents," on average (3.72), fear of low level of education (3.60), fear of moderation and favoritism with an average of 3.55. These fears show the awareness of young people and their follow-up to what is happening in the life of society.

Results related to the second question: Are there any statistically significant differences in the degree of fears among Jordanian youth due to the gender variable (males, females)? Table (3) shows the use of the mean and the T test in general, as can be seen from the following table.

Table (3) Mean, standard deviations and T-test of the effect of sex on the instrument

\begin{tabular}{|l|l|l|l|l|l|l|l|}
\hline & Gender & No. & Mean & $\begin{array}{l}\text { Standard } \\
\text { deviation }\end{array}$ & $\begin{array}{l}\text { t } \\
\text { value }\end{array}$ & $\begin{array}{l}\text { Freedom } \\
\text { Degree }\end{array}$ & $\begin{array}{l}\text { Statistical } \\
\text { significance }\end{array}$ \\
\hline $\begin{array}{l}\text { Self- } \\
\begin{array}{l}\text { Oriented } \\
\text { fears }\end{array}\end{array}$ & Male & $\mathbf{1 0 2}$ & $\mathbf{2 . 8 0}$ & $\mathbf{. 7 6 3}$ & - & $\mathbf{2 5 3}$ & $\mathbf{. 0 0 0}$ \\
\cline { 2 - 7 } & Female & $\mathbf{1 5 3}$ & $\mathbf{3 . 2 2}$ & $\mathbf{. 9 3 0}$ & $\mathbf{3 . 7 0 8}$ & $\mathbf{2 5 3}$ & $\mathbf{. 0 7 8}$ \\
\hline Social & Male & $\mathbf{1 0 2}$ & $\mathbf{3 . 1 4}$ & $\mathbf{. 8 2 0}$ & - & $\mathbf{2 5 3}$ & $\mathbf{- 1 3}$ \\
\hline
\end{tabular}


Jordanians' youth fears and their relationship to some variables

\begin{tabular}{|l|l|l|l|l|l|l|l|}
\hline fears & Female & $\mathbf{1 5 3}$ & $\mathbf{3 . 3 4}$ & $\mathbf{. 9 5 1}$ & $\mathbf{1 . 7 7 2}$ & & \\
\hline \multirow{2}{*}{ Total } & Male & $\mathbf{1 0 2}$ & $\mathbf{2 . 9 6}$ & $\mathbf{. 7 1 4}$ & - & $\mathbf{2 5 3}$ & .003 \\
\cline { 2 - 5 } & female & $\mathbf{1 5 3}$ & $\mathbf{3 . 2 8}$ & $\mathbf{. 8 8 9}$ & $\mathbf{2 . 9 7 2}$ & & \\
\hline
\end{tabular}

This is due to the prevalence of the unemployment rate among females rather than males, as well as the high rate of encephalopathy. This result differed with the study of Khalil and Jassim (2009), and study (ALhabes and ALKhutaba,M: 2015:89-91) .which showed no statistically significant differences. Of the gender variable.

Results related to the third question: Are there any statistically significant differences in the degree of fears of Jordanian youth due to the variable age group (15-18), (19-25) years?

To answer this question, the T-Test was used to find the effect of the age group to which young people are feared. The table shows the statistical averages and the standard deviations of the estimates of the sample members by age group.

Table (4)Meanal averages, standard deviations and t-test of the effect of age on the instrument.

\begin{tabular}{|c|c|c|c|c|c|c|c|}
\hline & Age & No. & Mean & $\begin{array}{l}\text { Standard } \\
\text { deviation }\end{array}$ & $\begin{array}{l}\mathrm{t} \\
\text { value }\end{array}$ & $\begin{array}{l}\text { Freedom } \\
\text { Degree }\end{array}$ & $\begin{array}{l}\text { Statistical } \\
\text { significance }\end{array}$ \\
\hline \multirow{2}{*}{$\begin{array}{l}\text { Self- } \\
\text { Oriented } \\
\text { fears }\end{array}$} & $\begin{array}{l}-15 \\
18\end{array}$ & 140 & 3.05 & .860 & \multirow[t]{2}{*}{.023} & \multirow[t]{2}{*}{253} & \multirow[t]{2}{*}{.982} \\
\hline & $\begin{array}{l}-19 \\
25\end{array}$ & 115 & 3.05 & .925 & & & \\
\hline \multirow[t]{2}{*}{$\begin{array}{l}\text { Social } \\
\text { fears }\end{array}$} & $\begin{array}{l}-15 \\
18\end{array}$ & 140 & 3.28 & .863 & \multirow[t]{2}{*}{.323} & \multirow[t]{2}{*}{253} & \multirow[t]{2}{*}{.747} \\
\hline & $\begin{array}{l}-19 \\
25 \\
\end{array}$ & 115 & 3.24 & .956 & & & \\
\hline \multirow[t]{2}{*}{ Total } & $\begin{array}{r}-15 \\
18\end{array}$ & 140 & 3.16 & .805 & \multirow{2}{*}{.178} & \multirow{2}{*}{253} & \multirow{2}{*}{.859} \\
\hline & $\begin{array}{l}-19 \\
25\end{array}$ & 115 & 3.14 & .876 & & & \\
\hline
\end{tabular}

Table (4) shows that there are no statistically significant differences ( $\alpha=0.05$ ) due to the effect of age in all fields and in the total score. This may be due to the similarity of the conditions faced by young people of different ages.

Results related to the fourth question: "Is there a difference between the estimates of the sample to the degree of feeling of fear among the Jordanian youth due to the variable of the institution to which they belong (school, youth center, university)"? 
In order to answer this question and to show the significance of the differences, a single variance analysis was used according to table (5).

Table (5) Analysis of the mono-variance of the institution's impact on the instrument as a whole

\begin{tabular}{|c|c|c|c|c|c|c|}
\hline & Source & $\begin{array}{l}\text { Total } \\
\text { squares }\end{array}$ & $\begin{array}{l}\text { Degrees } \\
\text { of } \\
\text { freedom }\end{array}$ & $\begin{array}{l}\text { Average } \\
\text { squares }\end{array}$ & Value $\mathrm{P}$ & $\begin{array}{l}\text { Statistical } \\
\text { significance }\end{array}$ \\
\hline $\begin{array}{l}\text { Self- } \\
\text { Oriented } \\
\text { fears }\end{array}$ & $\begin{array}{l}\text { Between } \\
\text { the } \\
\text { groups } \\
\text { In the } \\
\text { groups } \\
\text { Total }\end{array}$ & $\begin{array}{l}1.748 \\
198.770 \\
200.517\end{array}$ & $\begin{array}{l}2 \\
252 \\
254\end{array}$ & $\begin{array}{l}.874 \\
.798\end{array}$ & 1.108 & .332 \\
\hline $\begin{array}{l}\text { Social } \\
\text { fears }\end{array}$ & $\begin{array}{l}\text { Between } \\
\text { the } \\
\text { groups } \\
\text { In the } \\
\text { groups } \\
\text { Total }\end{array}$ & $\begin{array}{l}1.995 \\
205.962 \\
207.957\end{array}$ & 252 & $\begin{array}{l}.997 \\
.817\end{array}$ & 1.220 & .297 \\
\hline Total & $\begin{array}{l}\text { Between } \\
\text { the } \\
\text { groups } \\
\text { In the } \\
\text { groups } \\
\text { Total }\end{array}$ & $\begin{array}{l}1.859 \\
175.797 \\
177.657\end{array}$ & $\begin{array}{l}252 \\
242\end{array}$ & $\begin{array}{l}.930 \\
.698\end{array}$ & 1.33 & .266 \\
\hline
\end{tabular}

Table (5) shows that there are no statistically significant differences at the level of significance ( $\alpha=0.05$ ) due to the effect of the institution to which the youth belong because the calculated value (q) is less than the value (p) of the table. This may be due to the type of education, activities and experiences offered to young people in the school, the center and the university based on the promotion of personal growth among young people.

Question 5: Are there any statistically significant differences in the degree of fears of Jordanian youth regarding the fields of study (self, group)?

Table (6) Meanal averages, standard deviations and T-test between subjective and social fears 
Jordanians' youth fears and their relationship to some variables

\begin{tabular}{|c|c|c|c|c|c|c|}
\hline Age & No. & Mean & $\begin{array}{l}\text { Standard } \\
\text { variation }\end{array}$ & t value & $\begin{array}{l}\text { Freedom } \\
\text { average }\end{array}$ & $\begin{array}{l}\text { Statistical } \\
\text { significance }\end{array}$ \\
\hline $\begin{array}{l}\text { Self- } \\
\text { Oriented } \\
\text { fears }\end{array}$ & 255 & 3.05 & .889 & \multirow[t]{2}{*}{-5.190} & \multirow[t]{2}{*}{254} & \multirow[t]{2}{*}{000} \\
\hline $\begin{array}{l}\text { Social } \\
\text { fears }\end{array}$ & 255 & 3.26 & .905 & & & \\
\hline
\end{tabular}

Table 6 shows statistically significant differences $(\alpha=0.05)$ between self and social fears and in favor of social fears. This may be due to the youth's perception of their surroundings and complex conditions of unemployment, poverty, low level of education, the spread of moderation and favoritism, making them more fearful for their future This result is consistent with the Izgic et al (2004) study, which indicates that the social anxiety rate among students is $9.6 \%$. Those suffering from social fears have a negative and distorted perception.

\section{Suggestions and recommendations:}

1. Conduct more studies on the youth sector related to the needs of youth and psychological pressure.

2. Work on the deployment of youth centers where various sports and cultural activities are available.

3. Expand the deployment of counseling and counseling services in schools, centers and universities

\section{References}

1. Abu, Z. Medhat (2009). Child psychology, fear and phobia in children, 1, Dar Al Maarif University, Cairo, Egypt

2. Abu-Nasr, M. Mahmoud (2013). Social Service and Youth Welfare, 1, Makkah Al Mutanabi, Dammam, Saudi Arabia.

3. Al-Bahi, Z. Moawad (2009). The Family Environment and Meeting the Contemporary Challenges of Youth, Research published in the 20th Syrian Scientific Conference, Faculty of Social Work, Fayoum University, May 7.

4. Al-Fawwal, M. K. Hair (2006). Resist fear and individual behavior in children. (Philadelphia 11th International Conference, Fear Culture), Faculty of Education, University of Damascus, Syria 24-26 April.

5. Al-Rifa'i, N. (1985). Psychiatry and Psychotherapy, Part II, Trends in Psychological Outline, The Cooperative Printer, Damascus. 
6. Al-Sarhan, M, Qasham (2000). Communication skills among young people. Youth Education Series. (34) Issued by the Ministry of Youth and Sports in the Hashemite Kingdom of Jordan.

7. Al-Sha'rawi, A. Muhammad Gad. (1988). The sense of alienation and its relation to the various mental and non-mental variables among university students, Master Thesis, Faculty of Education, Mansouri University.

8. Al-Ghafri, N. (2013). Irrational Thoughts and its Relation to Social Fear among Students of Faculties of Applied Sciences in the Sultanate of Oman, Master's Thesis, University of Nizwa, Sultanate of Oman.

9. ALhabes, F. \& ALKhutaba, M. (2015). Social Phobia among Isra University students in Light of some Variables. Journal of psychology and Behaviourales Education, 3(2), 89-91.

10. Al-Harhasha, S. Ahmood (2014). Guidanceand guidance (practical guide for mentors and youth workers). 1. Dar Alkhalij, Publishing and Distribution, Amman, Jordan.

11. Al-Majdoub, A. (2000). Friendship and Youth, 1, Egyptian Lebanese House.

12. Bader, A. (2003). The level of orientation toward the future and its relation to some disorders among university youth. Egyptian Journal of Psychological Studies, Volume 13, (40), 34-82.

13. 4. Basher, Mammary (2009), Social Anxiety Erotic Attitudes Spread Rates Gender Differences, Journal of the Arab Psychological Network, Algeria, 21. 135136.

14. Baha Al-Din, T. (1998). Youth fears and needs in current circumstances. Unpublished research, University of Baghdad, Faculty of Education, Ibn Rushd. Iraq, April 15.

15. Center for Youth Studies and Research (2006). The reality of young people and their most important needs and trends towards their causes, Syrian Youth Union, Damascus.

16. Department of Statistics (2018). Statistical Yearbook. Amman 


\section{Jordanians' youth fears and their relationship to some variables}

17. Jassim and K. (2009). Psychological security and its relation to the feeling of psychological loneliness among the students of the preparatory stage, Journal of Psychological Sciences.25, 1-26.

18. Hikmat, A. (1988). Baghdad University students' fears. Unpublished MA, Baghdad University, Faculty of Education, Ibn Rushd, Baghdad.

19. Izgic, F., AKyuz, G.Dogan, o\&Kugu, N. (2004). Social phobia among university student and its relation to self-esteem and body image. The Canadian journal of psychiatry, 49(9), 630-634

20. Gerges, M. (1993). Child fears and lack of self-confidence causes prevention and treatment. 1, Library of love.

21. Rabee, M. (1991). Children's Fears and their Relationship to the Social Sector, 1, Morocco, Dar Al-Ulum.

22. Zahran, Hamid, A, Salam (2003). Social Psychology 6, World of Books and Printing, Cairo, Egypt.

23. Supreme Council of Youth (2001). Working paper entitled Higher Council for Youth reality and aspirations. Youth and Change Conference, Zarqa Private University, 21-22 / 4/2001.

24. Sheikli, A. (1995). The Concept of Youth Leadership Building Theory and Practice, Youth Education Series, (25). Issued by the Ministryof Youth in the Hashemite Kingdom of Jordan.

25. Shakil, Saba (1995). Building a training program to develop communication skills using the Mini Instructional Guidance. Unpublished PhD thesis, Faculty ofEducation, Mustansiriya University, Baghdad, Iraq.

26. Good. C. T. (1973). D. Cautionary of educational Psychology. New York. American.

27. Good W. \& Guze (1979). Psychiatric diagnosis. Oxford Univ. (PressOxford).

28. Mansouri, Khalid (1429 AH). The most common psychological and social problems and some personality traits in a sample of students of the Teachers College, Taif University, unpublished Master Thesis, Faculty of Education, Umm Al Qura University, Saudi Arabia. 
29. Pryank, N. (2013). Health, Social Sciences, problems college. Student Journal of Humanities and Social Sciences, 14(5); 21-34.

30. Wale, al-Obeidi. (2004). Clinical Psychology, 1, Dar Al-Thaqafa for Printing and Publishing. Jordan.

31. William, Al-Khuli (1976). Encyclopedia of Psychology and Mental Medicine. Cairo: Dar Al Ma'aref.

32. Williams,B\&Singh,S.(1999).Urban youth,Fear of a Crime and Tessellating Defensive Action, Adolescences,29,.11,323-33

Appendix (1)

The meanal averages and standard deviations of paragraphs as a descending order by meanal averages

\begin{tabular}{|c|c|c|c|c|}
\hline $\begin{array}{l}\mathrm{R} \\
\mathrm{a} \\
\mathrm{n} \\
\mathrm{k}\end{array}$ & Num & Item & Average mean & $\begin{array}{l}\text { Standard } \\
\text { deviation }\end{array}$ \\
\hline 1 & .18 & $\begin{array}{l}\text { I am afraid of the punishment of } \\
\text { God. }\end{array}$ & 4.20 & 1.328 \\
\hline 2 & .37 & Fear of drug proliferation. & 3.81 & 1.376 \\
\hline 3 & .38 & Fear of increasing road accidents. & 3.72 & 1.350 \\
\hline 4 & .34 & Fear of low level of education. & 3.60 & 1.353 \\
\hline 5 & .33 & Fear of modesty and favoritism. & 3.55 & 1.385 \\
\hline 6 & .20 & Fear of malignant diseases. & 3.53 & 1.433 \\
\hline 7 & .23 & Fear of pervasive moral deviations & 3.46 & 1.345 \\
\hline 8 & .14 & $\begin{array}{l}\text { I'm afraid I will not get a job after } \\
\text { graduation. }\end{array}$ & 3.43 & 1.459 \\
\hline 9 & .35 & Fear of low level of democracy. & 3.41 & 1.360 \\
\hline $\begin{array}{l}1 \\
0\end{array}$ & .29 & Fear of family disintegration. & 3.40 & 1.584 \\
\hline $\begin{array}{l}1 \\
1\end{array}$ & .21 & Fear of theft & 3.38 & 1.532 \\
\hline 1 & .25 & Fear of high costs of life. & 3.38 & 1.331 \\
\hline
\end{tabular}


Jordanians' youth fears and their relationship to some variables

\begin{tabular}{|c|c|c|c|c|}
\hline 2 & & & & \\
\hline $\begin{array}{l}1 \\
3\end{array}$ & .26 & Fear of the unknown future & 3.35 & 1.386 \\
\hline $\begin{array}{l}1 \\
4\end{array}$ & .36 & $\begin{array}{l}\text { The conflict between outlook and } \\
\text { reality }\end{array}$ & 3.35 & 1.288 \\
\hline $\begin{array}{l}1 \\
5\end{array}$ & .16 & I am afraid to fall in disrepute & 3.20 & 1.311 \\
\hline $\begin{array}{l}1 \\
6\end{array}$ & .15 & $\begin{array}{l}\text { I am afraid of the frustrations that } \\
\text { confront me. }\end{array}$ & 3.16 & 1.301 \\
\hline $\begin{array}{l}1 \\
7\end{array}$ & .24 & Fear of belonging to parties. & 3.16 & 1.460 \\
\hline $\begin{array}{l}1 \\
8\end{array}$ & .4 & I am afraid of making mistakes & 3.13 & 1.233 \\
\hline $\begin{array}{l}1 \\
9\end{array}$ & .5 & $\begin{array}{l}\text { I am afraid of talking about my own } \\
\text { problems }\end{array}$ & 3.13 & 1.427 \\
\hline $\begin{array}{l}2 \\
0\end{array}$ & .17 & I am afraid of death. & 3.12 & 1.618 \\
\hline $\begin{array}{l}2 \\
1\end{array}$ & .22 & $\begin{array}{l}\text { Worried about the lack of monthly } \\
\text { income of the family. }\end{array}$ & 3.12 & 1.341 \\
\hline $\begin{array}{l}2 \\
2\end{array}$ & .1 & Fear of misunderstanding & 3.10 & 1.235 \\
\hline $\begin{array}{l}2 \\
3\end{array}$ & .32 & $\begin{array}{l}\text { Fear of lack of family attention and } \\
\text { preoccupation with children }\end{array}$ & 3.07 & 1.471 \\
\hline $\begin{array}{l}2 \\
4\end{array}$ & .13 & $\begin{array}{l}\text { I fear the uselessness of the } \\
\text { testimony I will get }\end{array}$ & 3.04 & 1.504 \\
\hline $\begin{array}{l}2 \\
5\end{array}$ & .19 & Fear of erotic scenes & 3.01 & 1.512 \\
\hline $\begin{array}{l}2 \\
6\end{array}$ & .3 & I'm afraid to get into trouble. & 3.00 & 1.370 \\
\hline $\begin{array}{l}2 \\
7\end{array}$ & .27 & Fear of class differences & 2.95 & 1.413 \\
\hline $\begin{array}{l}2 \\
8\end{array}$ & .8 & I am afraid of unknown things. & 2.92 & 1.374 \\
\hline $\begin{array}{l}2 \\
9\end{array}$ & .10 & $\begin{array}{l}\text { I am afraid of my inability to } \\
\text { achieve my goals. }\end{array}$ & 2.90 & 1.468 \\
\hline $\begin{array}{l}3 \\
0\end{array}$ & .2 & I am afraid of wrong decisions & 2.89 & 1.215 \\
\hline 3 & .11 & I am afraid of failure to study & 2.89 & 1.512 \\
\hline
\end{tabular}


Journal of Social Sciences (COES\&RJ-JSS), 8(4), pp.594-610

\begin{tabular}{|c|c|c|c|c|}
\hline 1 & & & & \\
\hline $\begin{array}{l}3 \\
2\end{array}$ & .12 & $\begin{array}{l}\text { I am afraid of receding in some } \\
\text { materials. }\end{array}$ & 2.82 & 1.531 \\
\hline $\begin{array}{l}3 \\
3\end{array}$ & .31 & Fear of strict family restrictions. & 2.73 & 1.374 \\
\hline $\begin{array}{l}3 \\
4\end{array}$ & .7 & Fear of low self-concept. & 2.64 & 1.299 \\
\hline $\begin{array}{l}3 \\
5\end{array}$ & .28 & $\begin{array}{l}\text { Fear of mixing with the opposite } \\
\text { sex. }\end{array}$ & 2.63 & 1.492 \\
\hline $\begin{array}{l}3 \\
6\end{array}$ & .30 & Fear of growing family size. & 2.62 & 1.459 \\
\hline $\begin{array}{l}3 \\
7\end{array}$ & .9 & $\begin{array}{l}\text { I fear that my personality will not } \\
\text { be acceptable. }\end{array}$ & 2.50 & 1.422 \\
\hline $\begin{array}{l}3 \\
8\end{array}$ & .6 & Fear of speaking out loud. & 2.42 & 1.305 \\
\hline
\end{tabular}

Annex (2)

The meanal averages and standard deviations of the top five paragraphs in the first field are descending order

\begin{tabular}{|c|c|c|c|c|}
\hline $\begin{array}{l}\mathrm{Ra} \\
\mathrm{nk}\end{array}$ & Num & Item & Average mean & $\begin{array}{l}\text { Standard } \\
\text { deviation }\end{array}$ \\
\hline 1 & .18 & $\begin{array}{l}\text { I am afraid of the punishment of } \\
\text { God. }\end{array}$ & 4.20 & 1.328 \\
\hline 2 & .20 & Fear of malignant diseases. & 3.53 & 1.433 \\
\hline 3 & .14 & $\begin{array}{l}\text { I'm afraid I will not get a job after } \\
\text { graduation. }\end{array}$ & 3.43 & 1.459 \\
\hline 4 & .16 & I am afraid to fall in disrepute. & 3.20 & 1.311 \\
\hline 5 & .15 & $\begin{array}{l}\text { I am afraid of the frustrations that } \\
\text { confront me. }\end{array}$ & 3.16 & 1.301 \\
\hline
\end{tabular}

Annex (3)

The meanal averages and the standard deviations of the top five in the second field are descending order

\begin{tabular}{|l|l|l|l|l|}
\hline Rank & Num & Item & Average mean & $\begin{array}{l}\text { Standard } \\
\text { deviation }\end{array}$ \\
\hline
\end{tabular}


Jordanians' youth fears and their relationship to some variables

\begin{tabular}{|l|l|l|l|l|}
\hline $\mathbf{1}$ & $\mathbf{. 3 7}$ & Fear of drug proliferation & $\mathbf{3 . 8 1}$ & $\mathbf{1 . 3 7 6}$ \\
\hline $\mathbf{2}$ & $\mathbf{3 8}$ & $\begin{array}{l}\text { Fear of increasing road } \\
\text { accidents. }\end{array}$ & $\mathbf{3 . 7 2}$ & 1.350 \\
\hline $\mathbf{3}$ & $\mathbf{3 4}$ & $\begin{array}{l}\text { Fear of low level of } \\
\text { education. }\end{array}$ & $\mathbf{3 . 6 0}$ & 1.353 \\
\hline $\mathbf{4}$ & $\mathbf{. 3 3}$ & $\begin{array}{l}\text { Fear of modesty and } \\
\text { favoritism. }\end{array}$ & $\mathbf{3 . 5 5}$ & 1.385 \\
\hline $\mathbf{5}$ & $\mathbf{. 2 3}$ & $\begin{array}{l}\text { Fear of pervasive moral } \\
\text { deviations. }\end{array}$ & $\mathbf{3 . 4 6}$ & 1.345 \\
\hline
\end{tabular}

